PAEDAGOGIA CHRISTIANA

I/21 (2008) - ISSN 1505-6872

Zbigniew Formella*

Rzym

\title{
Religia jako integralny składnik wychowania skautowego w propozycji Roberta Baden-Powella
}

\section{Wstęp}

Lektura dzieł Roberta Baden-Powella (1847-1941) ${ }^{1}$ pod kątem wychowania religijnego pozwala nam na stwierdzenie, iż był on człowiekiem o pogłębionej, osobistej duchowości. Jego konkretne podejście do spraw religijnych jest widoczne również w praktycznych zasadach nakreślonych w propozycji wychowania skautowego. Z całą pewnością nie znajdziemy w tej propozycji usystematyzowanych przemyśleń teologicznych, jak i pedagogicznych. Baden-Powell nie jest teoretykiem wychowania, mającym szeroki warsztat naukowy do dyspozycji. Przedstawia się raczej jako osoba, pobudzana swoistą intuicją pedagogiczna, która próbuje rozwiązywać problemy w sposób bardzo konkretny i praktyczny. $Z$ całą pewnością jego pisma i wypowiedzi w tym zakresie, mimo że od śmierci założyciela skautingu minęło już blisko 70 lat, są ciagle mało znane, nawet instruktorom skautowym.

Jest natomiast dosyć dobrze znane wśród skautów zamiłowanie Baden-Powella do studiowania natury, podróży, poznawania kultury innych, nie wspominając o jego błyskotliwej karierze wojskowej. Jego głęboka wrażliwość na wymiar religijny jest naprawdę warta głębszej analizy, zwłaszcza dla zajmujących

* Zbigniew Formella, salezjanin, doktor nauk humanistycznych, profesor nadzwyczajny na Papieskim Uniwersytecie Salezjańskim w Rzymie. Kierownik Katedry Psychologii Wychowawczej na Wydziale Nauk o Wychowaniu.

${ }^{1}$ Najbardziej wyczerpującym opracowaniem, bazującym na szerokiej bibliografii, na temat Roberta Baden-Powella jest pozycja (w języku ang.): T. Jeal, Baden-Powell, New Haven and London 2001; Interesującą pozycją jest również wydana niedawno w języku ang.: R. Baden-Powell, Playing the game. A Baden-Powell Compendium, red. M. Sica, Londyn 2007. 
się wychowaniem skautowym, czy harcerskim. Taka pogłębiona analiza jego dzieł, pomoże nie tylko na ponowne odkrycie samej osoby twórcy skautingu jako wychowawcy, ale i jego propozycji wychowania skautowego, która nie powinna być przedstawiana młodzieży w często okrojonej formie, pozbawionej głębokiej wizji wychowania integralnego człowieka, w tym także aspektu religijnego. Jest to propozycja jak najbardziej aktualna, czego dowodem jest sam Ruch Skautowy na świecie, liczący w różnych swoich odmianach prawie 40 milionów członków, w ponad $200 \mathrm{krajach}^{2}$.

Celem niniejszego artykułu jest podkreślenie niektórych istotnych elementów wychowania religijnego w skautingu w propozycji Baden-Powella. W opracowaniu stosuję słownictwo związane ze skautingiem, co jednak analogicznie może być utożsamiane z polską jego odmianą, czyli harcerstwem. Bibliografia, która zastała wykorzystana przy opracowaniu jest w większości w języku włoskim. W nawiasach podane są tytuły dzieł Baden-Powella w języku angielskim. Tłumaczenia dokonane $\mathrm{z}$ tej okazji należą do autora niniejszego opracowania.

\section{Rodzina a wychowanie}

Na temat wpływu wychowania religijnego na rozwój osobowościowy Roberta Baden-Powella dowiadujemy się sporo z jego swego rodzaju autobiografii ${ }^{3}$. Ojciec Roberta był pastorem Kościoła anglikańskiego i jednocześnie profesorem geometrii na Uniwersytecie w Oxfordzie. Od niego też przejął on umiłowanie do lektury Pisma św., chociaż nie miał zbyt wielu okazji do przebywania z ojcem, ten, bowiem zmarł, kiedy Robert miał zaledwie trzy lata. Jego matka, Henriette Grace Smith, po zostaniu wdową, będąc kobietą o silnej osobowości i niezwykłym zmyśle praktycznym, z poświęceniem zajęła się rodziną. Pomimo trudnej sytuacji ekonomicznej, okazała się niezrównaną wychowawczynią swoich dzieci: prowadziła je na wycieczki po okolicach, zaszczepiała w nich ciekawość do poznawania życia zwierząt i roślin, uczyła obserwacji i podziwu wobec natury. Zamiast zmuszać swoje dzieci do czytania podręczników, rozwijała w nich ciekawość prowadzącą do osobistych poszukiwań poznawczych. Pomagali jej w tym, będący na emeryturze jej ojciec - admirał William Henry Smith, jej bracia i szwagier, wszyscy znawcy w dziedzinie nauk przyrodniczych. To doświadczenie rodzinne było źródłem pasji wobec poznawania tajemnic natury, trwającej u Baden-Powella przez całe życie.

Jako istotny element w wychowaniu Baden-Powell wspomina swoje głębokie relacje z braćmi, z którymi przeżywał wiele niezapomnianych przygód,

${ }^{2}$ Por. P. Bertolini, V. Pranzini, Pedagogia scout. Attualità educativa dello scautismo, Nuova Fiordaliso, Roma 2001.

${ }^{3}$ Por. Baden-Powella R., La mia vita come un'avventura, Ancora, Milano, 1985, [Lessons from the "Varsity of life"]; Por. także T. Jeal, dz. cyt. 
zwłaszcza w czasie wypraw wakacyjnych ${ }^{4}$. Jako piąty z szóstki braci, mocno związanych ze sobą, korzystał z ich przykładu, mającego na niego pozytywny wpływ: wszyscy bracia przejawiali różnorodne zainteresowania sportowe; dobrze pływali, grali w piłkę nożną i byli bardzo dobrymi wioślarzami. To w ich towarzystwie nauczył się zasady odpowiedzialności, dokładności, skrupulatności w wypełnianiu obowiązków, dyspozycyjności i posłuszeństwa, a w razie konieczności zachowania ,zimnej krwi” w obliczu niebezpieczeństwa, wytrzymałości na trudy, sztuki wyprodukowania wszystkiego tego, czego z różnych powodów nie można było kupić.

W roku 1868, mając 11 lat, zaczął uczęszczać przez dwa lata do szkoły w Tunbridge Wells, Rose Hill. Aby dotrzeć do szkoły, musiał przejść przez las Shadwell. To codzienne doświadczenie i możliwość obserwacji natury umocniło w im jeszcze bardziej zainteresowanie do jej poznawania, i pogłębiło w nim pasję do obcowania z przyroda. W latach 1870-76 uczęszczał do kolegium w Charterhouse, gdzie poza murami szkoły znajdował się tajemniczy wąwóz, pokryty lasem, ,zakazanie miejsce” dla chłopców z kolegium. Nie ukrywając swojej antypatii do szkoły, a przede wszystkim do metod w niej stosowanych, Baden-Powell spędzał tam sporo czasu, także w czasie zajęć lekcyjnych. Był to idealny teren dla młodego człowieka kochającego przygody, pragnącego odkrywać nowy, nieznany sobie świat, w którym może obserwować zwierzęta, tropić je po ich śladach, rozmyślać i snuć plany na przyszłość ${ }^{5}$. W ten sposób młody Baden-Powell studiował dwie ,wielkie księgi”, które uczą go o Bogu: Biblia i natura.

Wychodząc od tych dwóch niewyczerpanych źródeł, stopniowo poszerzają się jego horyzonty poprzez poznawanie nowych rzeczy, ludzi, a przede wszystkim siebie samego; religijność charakteryzuje się u niego zdolnością do wsłuchiwania się, dobroczynnością, ofiarnością i wymiarem wspólnotowym"6.

Te jego charakterystyczne cechy podkreślił również papież Jan Paweł II, w przesłaniu skierowanym do włoskich skautów katolickich AGESCI ${ }^{7}$ :

Wasz założyciel, Baden-Powell, uwielbiał dwie wielkie księgi, które i wy powinniście studiować: księgę natury i księgę Słowa Bożego, czyli Pismo św. Są to źródła ważne i bogate. Kochając przyrodę, żyjąc pośród niej i szanując ją, uczycie się łączyć wasz głos z tysiącem głosów lasu, które chwalą Stworzyciela; przebywając na łonie przyrody, przeżywacie wasze chwile modlitwy i liturgii, które pozostaną

${ }^{4}$ Por. tamże, s. 66.

5 Por. tamże, s. 32-35.

${ }^{6}$ Agesci, Sentiero fede. Il Progetto, Nuova Fiordaliso, Rzym 1997, s. 47.

${ }^{7}$ AGESCI - Associazione Guide e Scouts Cattolici Italiani [Katolickie Stowarzyszenie Skautów i Skautek Włoskich]. 
w waszych młodych sercach jako niezapomniane, głębokie przeżycia. Zachowując waszą tradycję i umiłowanie do poznawania Biblii, odkryjecie w niej wskazówki i drogi ciaggle nowe do oryginalnej i owocnej katechezy, należącej do nauczania Kościoła [włoskiego]i charakteryzującej się bogactwem symboliki momentów typowych dla skautingu"

\section{Jak rozumiał religię Baden-Powell?}

Baden-Powell nie podzielał rozdziału religii od wiary, czyli mówiąc inaczej, wiary od praktyk religijnych. Ta pierwsza, religia, miałaby się odnosić do wymiaru naturalnego człowieka i tym samym miałaby możliwość pewnych manifestacji zewnętrznych, mających służyć w sposób instrumentalny i funkcjonalny sprawom odnoszącym się do Boga. Droga ta w sposób mniej czy bardziej ukryty, kryje w sobie realne niebezpieczeństwo popadnięcia w idolatrię. Ta druga, odnosi się do wiary jako zawierzenia, na wzór drogi św. Pawła - ,posłuszeństwa w wierze", nierozerwalnie związana z głoszeniem Słowa Bożego, które gwarantuje człowiekowi, ,posłusznemu Słowu”, spotkanie z Bogiem żywym, który w pełni objawił się w Jezusie Chrystusie poprzez swoją śmierć i zmartwychwstanie?.

W swoim podstawowym dziele, Scouting for Boys, w 22 gawędzie tak oto definiuje religię:

Religia to bardzo prosta rzecz:

1. miłość Boga,

2. miłość i służba bliźnim ${ }^{10}$.

Wydaje się rzeczą oczywista, że poprzez to fundamentalne stwierdzenie o charakterze katechetycznym, koncepcja religii u Baden-Powella daleka jest od antytezy dotyczącej dwóch rodzajów podejścia do zagadnienia, tego naturalnego i tego ponadnaturalnego. Zostają one zjednoczone wokół przykazania miłości. W sposób jeszcze bardziej konkretny pokazuje to on sam w rozważaniach na temat Ewangelii:

Chrystus naucza nas w słowach bardzo konkretnych, jaka powinna być nasza religia, to znaczy: miłować Boga i miłować swojego bliźniego. Te dwie zasady są ponad ,prawem i prorokami”, ponad różnicami liturgicznymi i konfesyjnymi. Prze-

${ }^{8}$ Jan Paweł II, Przesłanie do Agesci, 2 sierpień 1997, z okazji narodowego zlotu instruktorów skautowych.

${ }^{9}$ Por. Neva M., La religione come fondamento dell'educazione scout, w: Brasca D. i inni, Idee e pensieri sull'educazione. Una rilettura di Baden-Powell, Fiordaliso, Rzym, 2007, s. 88-89.

${ }^{10}$ Lord Baden-Powell of Gilwell, Skauting dla chłopców. Wychowanie dobrego obywatela metoda puszczańska, Harcerskie Biuro Wydawnicze „Na Tropie”, Warszawa 1938, s. 279. 
kazywać ducha! Naszym zadaniem jako wychowawców-instruktorów jest starać się przekazywać to podstawowe przesłanie. Te same metody nie mogą być stosowane zarówno do starszych, jak i do młodych. Musimy uznać, że zasadniczo młody chłopiec nabywa właściwego ducha poprzez właściwe działanie, podczas gdy dorosły człowiek działa w konsekwencji posiadania właściwego ducha. Dlatego zachęcamy zuchów, i kontynuujemy tę zachętę wśród harcerzy, poprzez zwyczaj codziennego Dobrego Uczynku i w taki sposób, poprzez działanie, rozwija się w chłopcu duch dyspozycyjności do pomocy innym; aż do momentu, kiedy jako wędrownik, a potem osoba dorosła będzie inspirowany duchem gotów do poświęceń i służby na rzecz innych. Młody chłopak uczy się poprzez działanie, nie poprzez nabywanie wiedzy. „Miłować” jest dla niego tylko pewną abstrakcyjną koncepcją podczas gdy wyrażenie konkretne „pełnić służbę”, jest czymś, co może on uczynić, wykonać, podjąć się tego, i w tym jest duża różnica. Dlatego też, na potrzeby młodzieży powinniśmy przetłumaczyć ducha religijnego w konkretne działanie ${ }^{11}$.

Studiując teksty Baden-Powella, dotyczące spraw religijnych, odkrywamy wiele istotnych przemyśleń, często bazujących na intuicji, przedstawionych w sposób prosty a jednocześnie głęboki i tolerancyjny względem możliwości percepcyjnych każdego człowieka. Wyraźnie widoczna jest w nich inspiracja chrześcijańska, przedstawiona w sposób dostępny, chociaż nie zawsze teologicznie wyraźny. Nie należy jednak zapominać, iż twórca skautingu nie był teologiem, i w przeciwieństwie do swego ojca nie miał w tym zakresie przygotowania akademickiego. Wyraźnie widoczna jest natomiast próba przenikania się przemyśleń z dziedziny duchowości z ich aplikacjami praktycznymi.

Kiedy Baden-Powell, na wyraźne życzenie króla brytyjskiego Grzegorza V, poświęcił się pracy nad skautingiem, rezygnując z dalszej służby wojskowej, zapoznawał się z różnymi dziełami na temat wychowania; coraz bardziej dojrzewało w nim przekonanie o postrzeganiu wychowania jako przeżywanego doświadczenia, a nie tylko jako skutku nauczania. Wszedł w ten sposób w szeroki krąg wychowawczego ruchu brytyjskiego określanego mianem „New School”, czyli szkoły aktywnej ${ }^{12}$.

Baden-Powell postrzega rozwój religijny jako przeżycie, któremu towarzyszy dążenie do szczęścia, piękna, kontemplacja natury, jako związane z samą osobą Chrystusa i z przykazaniem miłości. Widzi on ponadto konieczność, aby dokonywało się ono w atmosferze optymizmu, który pozwala mu na rozwijanie w konsekwencji idei dialogu międzyreligijnego i tolerancji. Religia pełni tu rolę mocnego fundamentu, który zawiera w sobie podstawy do wskazywania bezpiecznego kierunku: prawdziwa i głęboka duchowość prowadzi w sposób pewny do horyzontów braterstwa międzynarodowego. Należy pamiętać, że rozwój skau-

${ }^{11}$ Cyt za: P. Dal Toso, Bevete la bell'aria di Dio. Pensieri di Baden-Powell sull'educazione religiosa, Quaderni del Centro Documentazione Agesci, Fiordaliso-Rzym 2007, s. 51-52.

${ }^{12}$ Por. M. Neva, dz. cyt., s. 88-89. 
tingu następował w czasach, w których świat przeżywał tragedię pierwszej wojny światowej i wielu konfliktów na tle narodowościowym. Dawny generał armii brytyjskiej z pewnością nie był wolny od przemyśleń na ten temat. Jego pozycja na temat konfliktów narodowościowych i zbrojnych prezentuje się z biegiem czasu jako coraz bardziej przeciwna temu sposobowi rozwiązywania problemów ludzkich ${ }^{13}$. Można śmiało powiedzieć, iż Baden-Powell, dzięki swojej religijności otwartej na dialog może być stawiany pomiędzy prawdziwymi protagonistami pokoju XX wieku a prekursorami Soboru Watykańskiego II.

\section{Wiara i learning by doing ${ }^{14}$}

Jedną z charakterystycznych cech metody skautowej jest praktycyzm. Oczywiście nie należy tego podejścia utożsamiać z utylitaryzmem. Jest to konsekwencja otrzymanego wychowania w rodzinie, szkolenia wojskowego i jego osobistego podejścia do życia. Nic więc dziwnego, iż tę samą zasadę stosuje do wychowania religijnego w odniesieniu do młodego człowieka. Widzimy to chociażby na przykładzie propozycji wdrażania zdrowego nawyku uprawiania gimnastyki połączonej z naturalną obecnością modlitwy codziennej:

Jeśli połączycie modlitwę z codziennymi ćwiczeniami, będziecie mieli okazję powiedzieć Bogu, podczas spoglądania w niebo: ,Jestem cały Twój, od głowy aż po nogi" i wdychajcie tę wspaniałą Bożą atmosferę (poprzez nos a nie ustami) ${ }^{15}$.

Jak łatwo zauważyć, Baden-Powell proponuje młodemu człowiekowi uprawiać gimnastykę i modlić się w tym samym czasie. Łączenie duchowości z ćwiczeniami ciała jest charakterystyczną cechą jego postrzegania integralnego rozwoju człowieka. Być może należy to przypisywać jego doświadczeniom wyniesionym z obserwacji duchowości innych kultur. Jest to pewne swoiste połączenie kontemplacyjności Wschodu z pragmatyzmem Zachodu ${ }^{16}$. Jego cechą charakterystyczną jest swoiste (angielskie) poczucie humoru, widoczne wyraźnie w stwierdzeniu ,jestem cały Twój, od głowy aż po nogi „czy też” wdychajcie tę wspaniałą Bożą atmosferę poprzez nos a nie ustami”, bo prawidłowy oddech dokonuje się tą drogą.

Kiedy mówimy w jego propozycji o pewnym „,naturalizmie religijnym”, czyli religii postrzeganej również i w samej naturze oraz $\mathrm{w}$ kontakcie $\mathrm{z}$ nią, nie powinni-

${ }^{13}$ Tematyka ta została w sposób interesujący przedstawiona w dziele: R. Baden-Powell, Cittadini del mondo. Scritti sulla pace, wstęp, wybór i thumaczenie M. Sica, Fiordaliso, Rzym 2006.

${ }^{14}$ Jest to jedna $\mathrm{z}$ charakterystycznych cech metody harcerskiej (należącej do szeroko rozumianej koncepcji szkoły aktywnej - nauczanie $w$ działaniu, podkreślające aktywny współudział wychowanka w procesie jego rozwoju). Por. P. Bertolini, V. Pranzini, dz. cyt.

${ }^{15}$ R. Baden-Powell, Manuale dei lupetti, Fiordaliso-Rzym 2006, s. 196-197 [The Wolf Cub's Handbook].

${ }^{16}$ Por. M. Neva, dz. cyt., s. 90-91. 
śmy zapominać, że Baden-Powell podkreśla tu przeżywanie doświadczeń w sposób fizyczny, bez niebezpieczeństwa popadania w panteizm. Chodzi w tym wszystkim o podkreślenie doświadczenia duchowości ludzkiej „fizycznie” ucieleśnionej. Dla znającego dobrze jego założenia wychowawcze, jak i napisane dzieła, nie istnieje niebezpieczeństwo alienacji religii osobowej, jaką jest chrześcijaństwo ${ }^{17}$.

Dokonując krytycznej analizy metod pedagogicznych swojego czasu i realiów, w których wzrastała młodzież, Baden-Powell zauważa, że lekcje katechizmu, w których młodzież brała udział, były raczej swoistą instrukcją wiary i moralności niż wychowaniem w wierze; co więcej, wychowanie religijne często sprowadzało się do pamięciowego opanowywania prawd wiary i nauczania prostego rytualizmu, poprzez obowiązek niedzielnego uczestnictwa w nabożeństwie, które często nie miało żadnego przełożenia na sposób życia w ciagu tygodnia. Baden-Powell widział w tym jeden z powodów, dlaczego liczni młodzi ludzie prezentowali ambiwalentny stosunek do przekonań religijnych i dlaczego ich przynależność do wspólnoty wyznaniowej często była zwykłą formalnością zewnętrzną, luźno związaną z wewnętrznymi przekonaniami religijnymi, wpływającymi na ich wybory moralne czy prezentowane postawy. Według jego propozycji natomiast ,skauting nie jest niczym innym jak chrześcijaństwem w praktyce" $" 18$.

Poza tym spadek czy wręcz zaprzestanie praktyk religijnych, według Baden-Powella, było spowodowane wysokim stopniem abstrakcji nauczanych reguł katechizmu w ich konfrontacji z codziennymi doświadczeniami młodych ludzi i ich ograniczonymi zdolnościami percepcji (ze względu na wiek i ograniczone możliwości studiowania), zwłaszcza w odniesieniu do młodzieży z uboższych klas społecznych. Widzi on ten problem jako wyraźne wyzwanie wobec wychowania religijnego. Można by je zsyntetyzować w propozycji, którą skierował do zuchów: „Kosztujcie zdrowej atmosfery Bożej”19. Także i w tym stwierdzeniu jawi się on jako wychowawca bardzo praktyczny i konkretny, który potrafi powiązać oryginalną i radosną syntezę duchowości z codziennym działaniem. Rzeczywiście nigdy osobiście nie związał się on z żadną konkretną szkołą mistycyzmu czy duchowości, ale też z drugiej strony nie popadł w zwykły akcjonizm.

Skauting nie zajmuje się krytyką jakiejkolwiek propozycji wychowawczej ${ }^{20}$. Nie przedstawia również założeń teoretycznych lub celów wychowawczych,

${ }^{17}$ W sposób syntetyczny na temat chrześcijaństwa i skutingu zob.: P. Alacevich (red.), Scautismo, umanesimo cristiano, Nuova Fiordaliso-Rzym 2003; G.-F. Morello Pieri (red.), Documenti pontifici sullo scautismo, Ancora, Milano 1991; G. Basadona, Scautismo e cristianesimo: sintesi genetica, w: F.-E. Iacono Frattini, Promessa scout: nelle parole una identità, Fiordaliso-Rzym 2005, s. 22-29.

${ }^{18}$ Cyt. za: P. Dal Toso, dz. cyt., s. 28.

${ }^{19}$ R. Baden-Powell, Manuale dei..., s. 196.

${ }^{20}$ Wyjątkiem w pwenym sensie mógłby tu być krytyczny stosunek Baden-Powella do ówczesnego systemu szkolnictwa angielskiego, wypływający zapewne w dużym stopniu z jego osobistych doświadczeń w tym względzie. 
które zawierają w sobie cele typu ,zachowuj się poprawnie”. Na poziomie metodycznym propozycja wychowawcza skautingu charakteryzuje się bezpośrednim włączeniem młodego człowieka, który poprzez Przyrzeczenie zobowiązuje się w sposób konkretny, aktywny, być wiernym Bogu ${ }^{21}$. Przyrzeczenie, jest sposobem nie tylko deklaracji, ale i dobrowolnego zobowiązania się do życia w wierności Bogu, co w praktyce oznacza nie tylko zaufanie Jego dobroci i nie zapominanie o Nim na co dzień, ale życie w Jego obecności, czyli w przyjaźni z Tym, kogo się wybrało, praktykując Jego wolę, czyli przykazania, na poziomie własnego rozeznania i możliwości ${ }^{22}$.

Dotrzymywanie danego Przyrzeczenia, przestrzeganie Prawa skautowego, spełnianie codziennego „Dobrego Uczynku”, jest w metodzie skautowej praktykowaniem zasad chrześcijańskich w życiu codziennym młodego człowieka. W rzeczywistości ten dobry uczynek nie jest środkiem do stania się automatycznie dobrym człowiekiem. Prowadzi on młodego człowieka do ugruntowania w sobie przyzwyczajenia do pełnienia dobra na rzecz innych, bycia dyspozycyjnym w razie konkretnej potrzeby społecznej, do wyrobienia w sobie wewnętrznego przekonania objawiającego się w ,normalnym przyzwyczajeniu” do dawania radości innym swoją konkretną pomocą, przezwyciężając w sobie w ten sposób naturalną skłonność do ,egoizmu”.

Baden-Powell wielokrotnie zachęca do dostrzegania konieczności niesienia pomocy innym, konkretnie i bez ociagania się. Czynienia tego, co możliwe w danym momencie i co od nas samych zależy, jakby nie było innej możliwości ze strony drugich lub w najbliższym czasie. Uważa to za najlepszy sposób konkretnego działania, kiedy młody człowiek przyjmuje postawę pozytywną i proaktywną wobec zaistniałej sytuacji, stając się w ten sposób chrześcijaninem nie w teorii, ale w praktyce ${ }^{23}$.

\section{Miłość podstawą każdej prawdziwej religii}

Niezależnie od przynależności do wyznania religijnego, Baden-Powell podkreślał, że w wychowaniu religijnym nowych pokoleń istotne jest wychowywanie do miłości wobec Boga, która wyraża się w służbie bliźnim. W każdym człowieku istnieje iskra miłości, która praktykowana, nabiera mocy i blasku każdego

${ }^{21}$ Tekst Przyrzeczenia skauta angielskiego brzmiał następująco: „Przyrzekam na swój honor uczynić wszystko, co leży w mojej mocy, by spełnić obowiązek względem Boga i Króla. Nieść pomoc bliźnim w każdej potrzebie. Być posłusznym prawu skautowemu”. Cyt. za: Lord Baden-Powell of Gilwell, Skauting dla chłopców..., s. 13. Więcej na temat ideału wychowania skautowego zob. w: Z. Formella, Chrześcijański ideat wychowawczy w Ruchu harcerskim w polsce po 1980 roku, Wydawnictwo Kujawskie, Inowrocław 2002.

${ }_{22}$ Por. G. M. Zanoni, „... per compiere il mio dovere verso Dio...”, w: F. Frattini, E. Iacono, Promessa scout..., s. 49-53.

${ }^{23}$ Por. Lord Baden-Powell of Gilwell, Skauting dla chłopców..., s. 259-262. 
dnia. Zachęcał do praktykowania służby w małych rzeczach, które prowadzą później do spełniania wielkich czynów, a jeśli zajdzie taka potrzeba, to nawet do poświęcenia swoich sił, czasu i zdrowia dla tych, którzy potrzebują mojego zaangażowania. Baden-Powell podkreślał: „Dąż do tego, aby to była Miłość, która kieruje twoim działaniem i twoimi myślami"24. Jest ponadto przekonany, iż im bardziej dzielimy się, obdarzamy miłością naszego bliźniego, tym bardziej ożywiamy w sobie tę ,cząstkę boskości”, która znajduje się w każdym człowieku, a która jest nasza dusza, aż do jej ostatecznego zjednoczenia się z Bogiem ${ }^{25}$. W ten sposób każdy człowiek jest w stanie znaleźć szczęście bycia „zawodnikiem w drużynie samego Boga”, oraz radość z udziału w szczęściu w niebie już teraz na ziemi.

W pismach Baden-Powella znajdziemy także teksty o modlitwie i jej potrzebie. Jak zwykle daje on konkretne wskazania na temat jak wychowywać chłopców do modlitwy. Zachęca, aby prosić o pomoc Boga w potrzebie, zwłaszcza, jeżeli stoi się przed jakimś trudnym wyzwaniem. Podkreśla także ważność modlitwy dziękczynnej. Przytaczam tu fragment listu, jaki napisał do pewnego pastora Kościoła anglikańskiego, który prosił go o wskazówki co do modlitw odmawianych na spotkaniach skautów w swojej wspólnocie:

Przykładam małą wagę do modlitw odmawianych według określonych tekstów, wyuczonych na pamięć. [...] Chłopiec powinien uczyć się modlić, a nie recytować modlitwy. Dałbym mu trzy wskazówki odnośnie modlitwy, którą pozostawiłbym, aby sam sobie sformułował [...]:

a) wdzięczność za łaski otrzymane;

b) zobowiązanie do odwdzięczenia się poprzez «dobre uczynki» spełnione wobec bliźnich;

c) prośba o pomoc, aby pozostać wiernym własnym zobowiązaniom [...]. Co do skautów, to nalegam, aby każdy scout modlił się przynajmniej rano i wieczorem, a także w innych momentach dnia $^{26}$.

W niepewności, czy podjąć działanie, zachęca, aby postawić sobie najpierw pytanie: „Co uczyniłby Chrystus na moim miejscu, w podobnej sytuacji?”27. Faktycznie, według Baden-Powella, Chrystus jest najlepszym wzorem i przykładem,

${ }^{24} \mathrm{R}$. Baden-Powell, La strada verso il successo. Libro per $i$ giovani sullo sport della vita, Fiordaliso-Rzym 2006, s. 19 [Rovering to Success].

${ }^{25}$ Por. R. Baden-Powell, Taccuino. Scritti sullo scautismo 1907-1940, Fiordaliso-Rzym 2001, s. 223 (wybór tekstów, thumaczenie, wstęp i opracowanie Mario Sica).

${ }^{26}$ Tekst pochodzi z roku 1909, opublikowany został w The Scouter w maju 1939 roku połączony z listem z 17 lutego 1910 roku. Znajduje się w centralnym archiwum scoutowym w Londynie. Cyt. za: Dodatek 4, w: R. Baden-Powell, Il libro dei capi, Firodaliso-Rzym 2006, s. 114-115 [Aids to Scoutmastership].

${ }^{27}$ Tenże, Guida da te la tua canoa. Pensieri per i giovani, Fiordaliso-Rzym 2006, s. 50 (wybór i thumaczenie Mario Sica). 
jaki możemy znaleźć: „Prawie wszystkie biografie zawierają w sobie rady, jak żyć, aby osiagnąć w życiu sukces, ale żadna z nich nie jest w stanie dać lepszych i pewniejszych rad niż ta Chrystusowa" ${ }^{28}$. Prawie wszyscy chłopcy, twierdzi Baden-Powell, mają szansę odkryć Chrystusa jako swojego bohatera, pod warunkiem, że będzie On im przedstawiany zgodnie z naturalnymi wymogami ich okresu rozwojowego. Nie jako osobowość patetyczna, ale jako osoba pełna siły i woli życia, odważna, szlachetna, mająca poczucie humoru, pogodna, i zdolna do zdrowych reakcji (nawet mocnych, jak to pokazuje wydarzenie z kupcami w świątyni jerozolimskiej - por. Mk 11, 15-17). Mając Chrystusa za wzór w momentach trudnych chłopiec ma konkretny punkt odniesienia ${ }^{29}$.

\section{Pokój i dobro w budowaniu Królestwa Bożego}

Żadna religia nie odrzuca pokoju i dobrej woli, które leżą u podstaw wychowawczych w propozycji skautingu, a które są konkretnym zaproszeniem do bycia aktywnym obywatelem: praktykować pokój i dobrą wolę oznacza konkretny i bezpośredni wkład w budowanie królestwa Bożego ${ }^{30}$. Dowodem skuteczności jest tutaj braterstwo skautowe, które rozwinęło się wśród skautów przekraczając barierę granic, kultur, ras, religii i wszelkich podziałów. Jest to przykład, który pozwala patrzeć z nadzieją na skuteczne budowanie przyszłości w cywilizacji miłości.

W okresie rozwoju skautingu, a jednocześnie okresie pomiędzy dwiema strasznymi wojnami o charakterze światowym, Baden-Powell snuje refleksję na temat wpływu szczerze praktykowanego chrześcijaństwa na braterstwo międzyludzkie i wzajemne zrozumienie: wojna rodzi się z powodu niedbania o rozwój związków braterstwa we wspólnocie ludzkiej, a podsycania drobnych różnic. $Z$ drugiej też strony, pomimo strasznych doświadczeń, zwłaszcza niezrozumiałych nacjonalizmów, których byliśmy świadkami, nie zamiera w nas na szczęście wyzwanie do działań na rzecz pokoju w respektowaniu różnic między nami, ponieważ wszyscy jesteśmy dziećmi tego samego $\mathrm{Ojca}^{31}$.

Pokój i dobra wola, które stoją u podstaw wychowania skautowego, są przez niego porównywane do swoistej „,religii”, będącej fundamentem każdego dialogu międzyludzkiego i międzyreligijnego:

Twierdzenie, iż pokój i dobra wola - zamiast wojna i zła wola - budują królestwo Boże na ziemi jest już z samej swej istoty «religią». Jest to rodzaj religii akceptowany przez wszystkich i żadne wyznanie religijne go nie odrzuca. Praktykowanie tej religii jest swoistą formą obowiązku obywatelskiego ${ }^{32}$.

\footnotetext{
${ }^{28}$ R. Baden-Powell, La mia vita ..., s. 16

${ }^{29}$ Por. tenże, Taccuino..., s. 224.

${ }^{30}$ Por. tenże, La mia vita ..., s. 307.

${ }^{31}$ Por. tenże, Taccuino ..., s. 181.

${ }^{32}$ Tenże, Cittadini del mondo..., s. 98.
} 
Aby móc budować królestwo Boże już tu na ziemi, konieczne jest wychowywanie młodych pokoleń do dobrej woli, wrażliwości i dyspozycyjności wobec potrzeb innych. Ten wyraźnie podkreślany przez Baden-Powella aspekt nie jest tylko prostym środkiem, czy drogą do realizacji celu, albo też upartością w realizowaniu postawionych sobie założeń, czy też iluzją dotyczącą możliwości zbawiania świata na wzór walki z wiatrakami, ale jest to głębokie przekonanie w możliwości realizacji, które razem z zaangażowaniem na polu wychowawczym, mogą przyczynić się do poprawy wizerunku tego świata, do realizacji przynajmniej w części królestwa pokoju i braterstwa wśród ludzi na ziemi.

I to jest właśnie zadanie (powołanie), które odkrył jako własne Baden-Powell, wyrażając przy tym świadomość należenia w tym względzie do planu Bożego. Tak też interpretuje rozwój i rozprzestrzenianie się w świecie skautingu, który na początku wydawał się interesująca, obok wielu innych, propozycją. Widzi je jako działanie człowieka, którym posłużył się Bóg, mając je w swoich planach. Sam Baden-Powell tak się wypowiada na ten temat:

Nie mogę nie zauważyć, że ten wszechstronny rozwój naszego Ruchu, zapoczątkowany wydawało się mało znaczącym doświadczeniem, jakim był «Scouting for Boys», był nie tylko pomysłem ludzkim, ale odkryciem inspiracji zapoczątkowanej przez Boga, w którym jeżeli działamy uczciwie, my Instruktorzy możemy bezpośrednio uczestniczyć, zarówno poprzez zachęty skierowane do naszych wychowanków, jak i poprzez przykład dany innym, o co zabiegają dzisiaj wszystkie narody, to jest pokój i dobro na świecie ${ }^{33}$.

Optymizm, który jest jedną z charakterystycznych cech osobowości twórcy skautingu, nie przejawia się w postawie swoistego dystansu wobec spraw lub traktowania ich powierzchownie. Rodzi się on z jego głębokiej duchowości, z przekonania, iż „od Boga wyszliśmy i do Niego zmierzamy”, które prowadzi go do stawienia czoła realiom życia, a także jego zakończenia z ufnością i spokojem spełnionego obowiązku. Nie brakuje mu przy tym jak zwykle poczucia humoru:

Pewien chłopiec, który miał opinię niepoprawnego, został doprowadzony pewnego dnia przed trybunał; usprawiedliwiając swoje złe postępowanie stwierdził, że była to wina Pana Boga: «Gdyby Bóg nie chciał, żebym był zły, uratowałby mnie i sprawił, iżbym był dobry». To wydarzenie przypomina mi jednego z dowódców Boerów, kiedy został schwytany przez nasz oddział, odparł, że to wina prezydenta Krugera, który nie dostarczył mu w sposób wystarczający artylerii. Opowiedział, że kiedy poprosił Prezydenta, ten dał mu taką odpowiedź: «Jeśli Bóg zechce, iż zwyciężymy my tę wojnę, zwyciężymy więc, czy to z pomocą artylerii, czy też bez niej». Na to ten mu odparł: «To prawda. Jednak Bóg dał wam żołądek, z którym możecie rozkoszować się smakiem pieczonej kaczki; ale zakłada On, że to wy ją opierzycie

${ }^{33}$ Tenże, Cittadini..., s. 83. 
i upieczecie». Nic bardziej prawdziwego: Bóg dał nam na tym świecie wszystko to, czego potrzebujemy, aby żyć, ale zależy od nas wykorzystanie tych możliwości lub ich zaprzepaszczenie. Ponieważ mamy stosunkowo mało czasu do dyspozycji na tej ziemi, jest ważne czynić tylko to, co jest wartościowe i czynić to bez odkładania na później. [...] W moim przypadku, od lat powtarzam sobie: «Za trzy lata umrę; tak więc muszę zrobić wszystko, aby doprowadzić moje sprawy do końca, inaczej nie zdążę!». To przyzwyczajenie pomaga mi czynić natychmiast to, co może odłożone na później, nigdy nie byłoby zrealizowane ${ }^{34}$.

\section{Zakończenie}

Uważna lektura dzieł Baden-Powella, pod kątem jego propozycji na temat wychowania do wiary, prowadzi do odkrycia cechy jego osobowości jako wychowawcy prawdopodobnie w wielu kręgach nieznanej. Z jego głębokiej duchowości pochodzą także konkretne wskazania, w jaki sposób prowadzić, nauczać chłopców osobistego dialogu z Bogiem.

Bardzo interesujące są dla nas dzisiaj, po upływie 100 lat od powstania skautingu, niektóre obserwacje czy też intuicje wychowawcze Baden-Powella, który wydaje się w swoich propozycjach wychowania religijnego wyprzedzać w wielu określeniach dzisiejsze zasady wychowania do wiary. Dotyczy to zwłaszcza jego poglądów na temat braterstwa skautowego, które nie czyni różnicy w przynależności do klasy społecznej czy narodowości. W rzeczywistości nie podkreślał on wyższości jednego wyznania religijnego nad drugim, ale koncentrował się na jego praktykowaniu ${ }^{35}$ : pomóc chłopcom spełniać ich obowiązi wobec Boga poprzez zaangażowanie w codzienne obowiązki, także te wobec drugich. Jest to konkretny sposób życia, który może prowadzić do życie „sukcesu”. Aby kroczyć drogą prowadzącą do szczęścia, należy zadbać o solidne podstawy życia religijnego. Religijność jest więc w skautingu jednym z istotnych elementów wychowania integralnego i należy do jego nienaruszalnych fundamentów.

W obecnym społeczeństwie, coraz bardziej wielokulturowym i wieloreligijnym, powstaje pytanie, w jaki sposób praktycznie rozwiązywać ten problem, kiedy w jednej drużynie skautowej są należący do różnych religii. W wielu krajach europejskich jest to zjawisko codzienne. Powstrzymując się od prostego prozelityzmu, rozwiązania należy poszukiwać, szanując wolność religijną każdego, według wskazówek, które dał na ten temat Baden-Powell. Z drugiej strony, w momencie, w którym wskazuje się na podstawowe wartości, jak miłość Boga, bliźniego i siebie samego, mamy już odpowiedź co do pełnej otwartości i współpracy opartej na tych podstawowych zasadach, które w humanizmie chrześcijańskim znajdują swoje pełne odbicie.

\footnotetext{
${ }^{34}$ Tenże, La strada..., s. 23-24.

${ }^{35}$ Por. R. Baden-Powell, Il libro dei..., s. 66-67.
} 
Post scriptum

Baden-Powell's Last Message to Scouts ${ }^{36}$

Dear Scouts,

If you have ever seen the play Peter Pan you will remember how the pirate chief was always making his dying speech because he was afraid that possibly when the time came for him to die he might not have time to get it off his chest. It is much the same with me, and so, although I am not at this moment dying, I shall be doing so one of these days and I want to send you a parting word of good-bye.

Remember, it is the last you will ever hear from me, so think it over.

I have had a most happy life and I want each one of you to have as happy a life too.

I believe that God put us in this jolly world to be happy and enjoy life. Happiness doesn't come from being rich, or merely from being successful in your career, nor by self-indulgence. One step towards happiness is to make yourself healthy and strong while you are a boy, so that you can be useful and so can enjoy life when you are a man.

Nature study will show you how full of beautiful and wonderful things God has made the world for you to enjoy. Be contented with what you have got and make the best of it. Look on the bright side of things instead of the gloomy one.

But the real way to get happiness is by giving out happiness to other people. Try and leave this world a little better than you found it and when your turn comes to die, you can die happy in feeling that at any rate you have not wasted your time but have done your best. "Be Prepared" in this way, to live happy and to die happy - stick to your Scout promise always - even after you have ceased to be a boy - and God help you to do it.

Your friend

Baden-Powell

\section{Relgione come un composto della educazione di scout nella proposta di Robert Baden-Powell (Riassunto)}

Baden-Powell, che non volle definire il suo metodo una rivoluzione nel sistema d'educazione ma semplicemente un gioco pieno d'allegria sintetizzava in quattro punti il

${ }^{36}$ Przytaczam w tym miejscu oryginalny tekst „testamentu Baden-Powella”, który miał być opublikowany po jego śmierci. Nie ma na nim daty. Prawdopodobnie został napisany przed jeszcze rokiem 1929. Wskazywałby na to podpis pod tekstem - Baden-Powell (zamiast Baden-Powell of Gilwell). Według świadectwa żony, Baden-Powell nosił go zawsze przy sobie w swoich podróżach w małej kopercie z napisem ,dla Skautów”, która znajdowała się w większej kopercie z napisem „na wypadek mojej śmierci”. 
contributo che lo scautismo poteva dare all'educazione: formazione del carattere, sviluppo dell'abilità manuale, rinvigorimento della salute, servizio del prossimo.

Nonostante il passare degli anni e i cambiamenti socio-culturali avvenuti nel frattempo, le intuizioni educative contenute nello scautismo non hanno perso di validità e di credibilità. Il fondatore dello scautismo dimostra il buon senso e l'equilibrio in tutti suoi scritti pedagogici. Lo vero spirito scout, secondo lui, è un modo di vivere con successo la vita; un successo, quello di cui parla Baden-Powell che lungi dall'essere costituito dalla ricchezza, dalla potenza o da brillante carriera professionale, consiste più semplicemente nell'essere felici. Non certo, si badi, in un modo passivo, perché allora si tratterebbe di piacere e non di felicità ma in un modo profondamente attivo nel quale il giovane impegni tutto il suo essere, come dice Baden-Powell, dalle braccia e dalle gambe fino al cervello e all'intelligenza.

Il tema principale di quest'articolo è la dimensione religiosa nella proposta scout secondo il Suo Fondatore. Baden-Powell non ha voluto associare lo Scautismo ad una confessione religiosa per non creare ostacoli all'universale fraternità, ma, da persona di fede, riteneva la dimensione religiosa determinante per la felicità di ogni uomo (,, Se vuoi veramente intraprendere la strada verso il successo, cioè verso la felicità, devi dare una base religiosa alla tua vita"). Il metodo scout si può considerare come uno straordinario strumento educativo che ha concreta possibilità d'annuncio e di realizzazione del messaggio evangelico e di vita cristiana per le seguenti ragioni: l'obiettivo dell'educazione scout è l'uomo integrale nello sviluppo di tutte le sue energie e potenzialità; la proposta religiosa si colloca perciò dentro l'esperienza complessa del ragazzo; l'educazione religiosa nello scautismo non è mai soltanto riflessione e preghiera, ma contemporaneamente, è azione, ricerca, vita attiva. Lo stesso Baden-Powell a chi gli chiedeva cosa centrasse la religione con lo scautismo rispondeva: „la religione non deve entrarci perché è già dentro. Essa è il fatto fondamentale che possiede lo scautismo e il guidiamo". 